\title{
BULLETIN of The BUSINESS HISTORICAL SOCIETY
}

INCORPORATED

BAKER LIBRARY, SOLDIERS FIELD, BOSTON, MASS. RaLPh M. Hower, Editor

Vol. $X$, No. 2 APRIL, 1936 Whole No. 59

\section{Annual Meeting of the Society April 22, 1936}

The annual meeting of the Business Historical Society will be held at the Harvard Business School on Wednesday, April 22, 1936, at twelve noon. Final arrangements have not yet been completed, but the program will include a short business meeting, a subscription luncheon at the Faculty Club; and two addresses on topics related to business history. During the business meeting the officers for the ensuing year are to be elected, including the Treasurer, the Clerk, and the seven members of the Council. Members are reminded that both General and Affiliated Members are now entitled to vote, as a result of the changes in the Constitution and By-laws voted last May, and that they may attend the meeting by proxy. Individual notices will have been mailed to members before the appearance of this issue of the Bulletin.

\section{The Oldest American Business Corporation in Existence}

THERE Is a good deal of doubt as to which was the earliest business corporation in America. One view is that a whale-fishing company established in New York City in 1675 was the first, but, although a joint-stock company (a kind of partnership), there is no evidence that it was also a corporation.-A second view is that the first was The New London Society United for Trade and Commerce, chartered, apparently, in Connecticut in 1732. The life of these and other $[21]$ 